\title{
RECORD OF GYRODACTYLUS BYCHOWSKIANUS BOGOLEPOVA, 1950 (MONOGENEA, GYRODACTYLIDAE) FOR THE FIRST TIME IN IRAQ FROM GILLS OF THE CYPRINID FISH ARABIBARBUS GRYBUS
}

\author{
Fatima Abd Razak Sheyaa and Kefah Naser Abdul-Ameer* \\ Department of Biology, College of Education for Pure Science, University \\ of Baghdad, Baghdad, Iraq \\ *Corresponding author e-mail: kefahnaser59@yahoo.com
}

Received Date: 30 November 2018, Accepted Date: 24 February 2019, Published Date: 27 June 2019

\begin{abstract}
The monogenean Gyrodactylus bychowskianus Bogolepova, 1950 is recorded in the present study for the first time in Iraq from the gills of the cyprinid fish Arabibarbus grypus (Heckel, 1843); which was collected from the Tigris River at Al-Taji Beach north of Baghdad Province during the period from July until November 2018.
\end{abstract}

Keywords: Arabibarbus, Cyprinid, Gyrodactylus, Iraq, Monogenea.

\section{INTRODUCTION}

The genus Gyrodactylus is one of 23 genera of the family Gyrodactylidae, with 19 viviparous genera and four oviparous genera (Bakke et al., 2007); this genus has the widest host range of any monogenean family, being found on 19 orders of bony fishes (Bakke et al., 2002). Species of Gyrodactylus von Nordmann, 1832 which have direct life cycle (without intermediate hosts) are common ectoparasites of fishes, living on the skin, fins and gills of many of teleost fishes and occur in freshwater and brackish and marine environments, but relatively few species are euryhaline (Buchmann and Bresciani, 2006). Bakke et al. (2007) reported that some Gyrodactylus species infect only the gill filaments, others may occur on gill arches and in the pharynx; the initial colonisation appears random (parasites attach anywhere on the body surface), followed by migration to a specific site, the caudal fin followed by the pectoral and pelvic fins.

In Iraq, the first gyrodactylid species, Gyrodactylus elegans von Nordmann, 1832 was reported from gills of both Cyprinus carpio and Planiliza abu (which was reported as Liza $a b u$ ) by Ali and Shaaban (1984); later on, many studies on parasites of fishes from different water bodies of Iraq revealed the record of 51 species which have been described from different freshwater fishes (Mhaisen, Pers. Comm.). Therefore, more surveys on fish parasites are needed to identify more species and to match the growing information on the parasitic fauna of freshwater fishes of Iraq.

The present study reported Gyrodactylus bychowskianus Bogolepova, 1950 from gills of the cyprinid fish Arabibarbus grypus (Heckel, 1843) which was collected from the Tigris River at Al-Taji Beach of north Baghdad for the first time in Iraq.

\section{MATERIALS AND METHODS}

During the period from July until November 2018, a total of ten specimens of Arabibarbus grypus were collected weekly from the Tigris River at Al-Taji Beach north of Baghdad 
province $\left(33^{\circ} 27^{\prime} 19^{\prime} \mathrm{N}, 44^{\circ} 20^{\prime} 58^{\prime} \mathrm{E}\right)$. The fishes were transported alive to the laboratory and freshly examined for ectoparasites; skin and gill smears were microscopically examined; care was taken to isolate and flatten the parasite specimens which then were stained by aqueous neutral red, and permanent slides were prepared with glycerol-gelatin. The drawings of sclerotized pieces of the haptor were made by using a camera Lucida (Olympus).

Parasite identification was performed according to Pugachev et al. (2009); all measurements used in the description are presented in the following order: minimum-maximum (mean) values; the fishes were identified according to Coad (2010) and the scientific name of the fish was used according to Harris et al. (2004).

\section{Gyrodactylus bychowskianus Bogolepova, 1950}

\section{RESULTS AND DISCUSSION}

Two out of 10 of Arabibarbus grypus, were infected with this parasite which was found on the gills of the infected fishes; the measurements (in $\mathrm{mm}$ ) were based on five specimens of parasites. The following is a brief description and measurements of this parasite as shown in Plate (1).

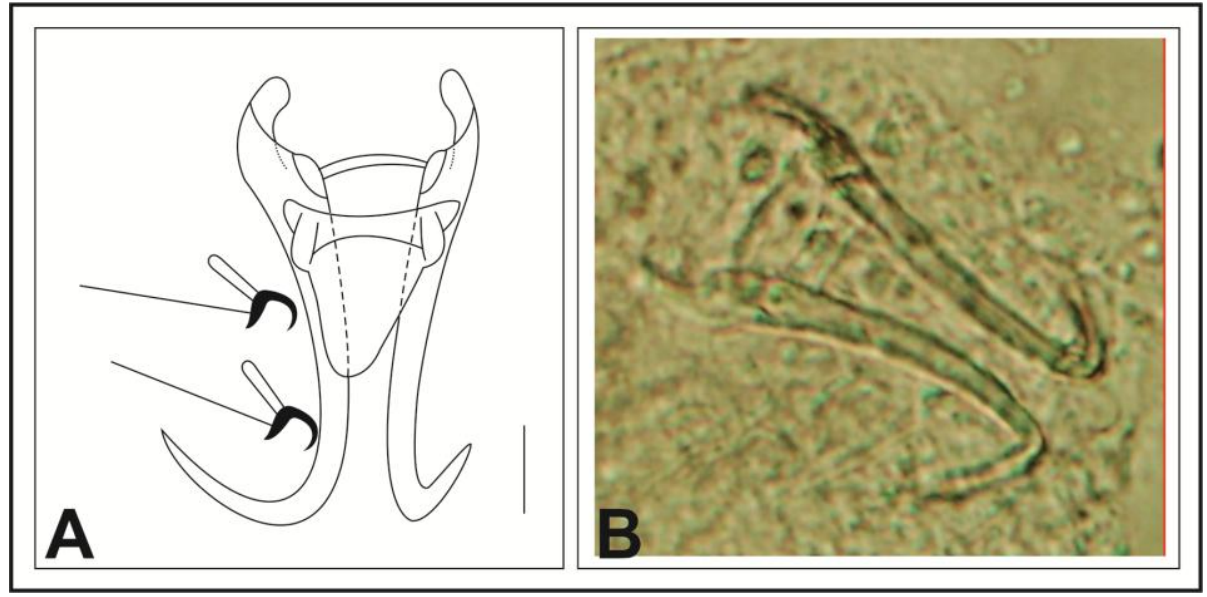

Plate (1): Gyrodactylus bychowskianus; (A) Camera Lucida drawing of the haptor, (Scale bar $=0.017 \mathrm{~mm}),(\mathrm{B})$ Photomicrograph of the haptor $(400 \mathrm{x})$.

Body length 0.39-0.43 (0.42); total length of marginal hooks 0.034-0.036 (0.035), hooklet 0.008 ; total length of anchor 0.08-0.084 (0.082), main part 0.074-0.076 (0.075), point 0.0220.026 (0.024); size of ventral bar 0.006 x $0.035-0.038$ (0.036), membrane 0.012 ; size of dorsal bar $0.002 \times 0.016-0.02(0.018)$.

The description and measurements of the present G. bychowskianus are in agreement with those reported by Pugachev et al. (2009) from gills of Cottocemephorus grewingkii and C. inermis, Lake Baikal.

The present report of $G$. bychowskianus reports the first record in Iraq, as no previous record has been given for this parasite from fishes of Iraq; with the present record of Gyrodactylus bychowskianus Bogolepova, 1950 number of Gyrodactylus species from the fishes of Iraq so far reaches 52 species in different parts of Iraq. 
In Iraq, many species belonging to the genus Gyrodactylus were so far reported from freshwater fishes from various water bodies, among which some were reported from $A$. grypus; the following is list of these species with the mention of only the first record for each Gyrodactylus species from A. grypus: Gyrodactylus elegans Nordmann, 1832 from Diyala River (Ali et al., 1986), Gyrodactylus markevitschi Kulakovskaya, 1952 from the Euphrates River in Al-Musaib City (Al-Sa'adi, 2007), Gyrodactylus sprostonae Ling, 1962 and Gyrodactylus tincae Malmberg,1957 from Al-Graiat region at Tigris River at Baghdad province (Abdul-Ameer and Atwan, 2017), with the present record of G. bychowskianus, five of Gyrodactylus species so far reported from A. grypus in Iraq and the number of Gyrodactylus species from fishes of Iraq so far reaches 52 species in comparison with 25 Gyrodactylus species which were known from fishes of Iraq till 2013 according to Mhaisen and Abdul-Ameer (2013).

\section{ACKNOWLEDGEMENTS}

Thanks are due to Prof. Dr. Furhan T. Mhaisen for his permission to use his indexcatalogue of parasites and disease agents of fishes of Iraq to provide us the information on the previous account records of parasites in Iraq and the number of Gyrodactylus species from the fishes of Iraq in different parts of Iraq.

\section{LITERATURE CITED}

Abdul-Ameer, K. N. and Atwan, F. K. 2017. First record of four species of the genus Gyrodactylus Nordmann 1832 (Monogenea: Gyrodactylidae) from some Iraqi freshwater fishes. Sciences (Proceedings of the Third Scientific Conference of the Faculty of Veterinary Medicine / University of Kerbala on 10th April 2017): 289-297.

Ali, M. D. and Shaaban, F. 1984. Some species of parasites of freshwater fish raised in pond and in Tigris-Al-Tharthar canal region. Seventh Scientific Conference Iraqi Veterinary Medicine Association, Mosul: 23-25, Oct. 1984: 44-46. (Abstract).

Ali, N. M., Al-Jafery, A. R. and Abdul-Ameer, K. N. 1986. New records of three monogenetic trematodes on some freshwater fishes from Diyala River, Iraq. Journal of Biological Science Research, 17(2): 253-266.

Al-Sa'adi, B. A. -H. E. 2007. The parasitic fauna of fishes of Euphrates River: Applied study in Al-Musaib city. Master of Technology Thesis, Al-Musaib Technical College, Foundation of Technical Education, 102 pp. (In Arabic).

Bakke, T. A., Cable, J. and Harris, P. D. 2007. The biology of gyrodactylid monogeneans: the "Russian-doll killers". Advances in Parasitology, 64: 161-376.

Bakke, T. A., Harris, P. D. and Cable, J. 2002. Host specificity dynamics: Observations on gyrodactylid monogeneans. International Journal for Parasitology, 32(3): 281-308.

Buchmann, K. and Bresciani, J. 2006. Monogenea (Phylum: Platyhelminthes). In: Woo, P.T.K. (ed.); fish diseases and disorders, Vol. 1: Protozoan and metazoan infections, $2^{\text {nd }}$ Edition, CAB International, Wallingford, p297-344.

Coad, B. W. 2010. Freshwater fishes of Iraq. Pensoft Publisher, Sofia, 274 pp. + 16 pls.

Harris, P. D., Shinn, A. P., Cable, J. and Bakke, T. A. 2004. Nominal species of the genus Gyrodactylusv. Nordmann 1832 (Monogenea: Gyrodactylidae), with a list of principal host species. Systematic Parasitology, 59: 1-27. 


\section{Record of Gyrodactylus bychowskianus Bogolepova}

Mhaisen, F. T. and Abdul-Ameer, K. N. (2013). Checklists of Gyrodactylus species (Monogenea) from fishes of Iraq. Basra Journal of Agricultural Sciences, 26 (Spec. Issue 1): 8-25.

Pugachev, O. N., Gerasev, P. I., Gussev, A.V., Ergens, R. and Khotenowsky, I. (eds). 2009. Guide to Monogenoidea of freshwater fish of Palaearctic and Amur regions. Ledizioni-Ledi Publishing, Milano, 567 pp. 
Fatima Abd Razak Sheyaa and Kefah Naser Abdul-Ameer

Bull. Iraq nat. Hist. Mus.

June, (2019) 15 (3): 287-291

تسجيل النوع Gyrodactylus bychowskianus Bogolepova, 1950

(Monogenea, Gyrodactylidae)

Arabibarbus grypus لأول مرة في العراق من غلاصهم سمكة الشبوط

$$
\begin{aligned}
& \text { فاطمة عبد الرزاق شياع و كفاح ناصر عبد الأمير }
\end{aligned}
$$

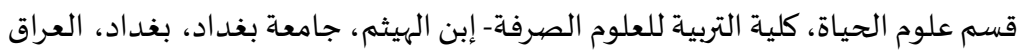

$$
\begin{aligned}
& \text { تأريخ الستلام: .r/1 }
\end{aligned}
$$

\section{الخلاصة}

Gyrodactylus أظهر فحص غلاصهم سمكة الكارب الاعتيادي سجل الطفيلي أحادي المنشأ bychowskianus Bogolepova, 1950 الشبوط Arabibarbus grypus (Heckel, 1843) من العائلة الشبوطية، التي جمعت من نهر دجلة

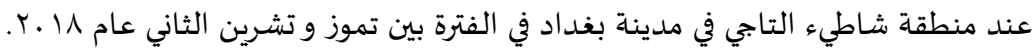

